\title{
Law Protection forward Privacy Data of Social Media User According to International and National Law
}

\author{
Febilita Wulan Sari \\ Faculty of Law \\ Universitas Komputer Indonesia \\ Bandung, Indonesia \\ febilita.wulan.sari@email.unikom.ac.id
}

\begin{abstract}
The research on the law protection forward privacy data of social media users aims to find the concept of international law and the concept of the national legal system in providing protection for the privacy data of social media users and the extent to which the current law protection is implemented in the effort to protect the privacy of social media users. The research method was analytical descriptive with a normative juridical approach and the resulting data was analyzed qualitatively juridical with library research and field research techniques. The results study show that international provisions privacy data protection has been spread in various international conventions including the $U D H R$, while the provisions related to the protection of data privacy in Indonesia are currently regulated in general in several relevant laws. The various national provisions have not been able to provide legal protection optimally due to legal constraints and non-legal constraints, including legal obstacles related to the absence of specific regulation of privacy data protection and legal mechanisms. The provision of data on the privacy of social media users specifically, both internationally and nationally is needed as a normative juridical, and must be followed by maximum implementation.
\end{abstract}

Keywords—legal protection, privacy data, and social media.

\section{INTRODUCTION}

Information technology is a rapidly developing field, the influence of its development is not only felt in one aspect of life but all aspects of life. One aspect that experiences changes related to the development of information technology is the aspect of interpersonal relationships, where the current development of interpersonal relationships can be carried out with various conveniences and effectiveness, namely by using social media. The emergence of social media in addition to providing ease of communication, but also raises new problems related to the protection of users' privacy data. Social media can be used to establish connections and connect with other internet users. However, the privacy data that is on social media is often used for things beyond the user's knowledge, even privacy data violations can occur without the individual being aware of it.

At present, there are many studies on the protection of personal data, including research from Elena Izyumenko [1] entitled "Think before you share: Personal Data on the Social Networking Sites in Europe: Article 8 ECHR as a tool of Privacy Proection"; (2) Research from Brendan van Alsenoy, entitled "Regulating Data Protection, The Allocation of
Responsibility and Risk among Actors Involved in Personal Data Processing" ; (3) Patricia Sánchez Abril, Avner Levin, and Alissa Del Riego entitled " Blurred Boundaries: Social Media Privacy and the Twenty-First-Century Employee" ; (4) Juliane Kokott and Christoph Sobotta who reviewed the distinction between privacy and data protection in the jurisprudence of the CJEU and the EctHR ; and (5) research from Francesca Bignami, namely Privacy and Law Enforcement in the European Union: The Data Retention Directive conducted by Francesca Bignami.

Research by Elena Izyumenko entitled "Think before you share: Personal Data on the Social Networking Sites in Europe: Article 8 ECHR as a tool of Privacy Protection". The research is aimed at finding out how the European legal system may approach the challenges of online social networking and their privacy effects in personal data protection of the European users. [1] His research aimed specifically at researching data protection in social networks in Europe. Another research is Brendan van Alsenoy's research entitled "Regulating Data Protection, The Allocation of Responsibility and Risk among Actors Involved in Personal Data Processing". The thesis as to determine whether EU data protection law should maintain its current distinction between controllers and processors as the basis for allocating responsibility and risk. Specifically, it will determine whether it will be possible to modify the current approach, which would increase legal certainty, without diminishing the legal protections enjoyed by data subjects. The thesis concludes that while the GDPR introduces Considerable improvements, a number of Recommendations can still be made. [2] The research was good and was specifically aimed at the study of EU data protection law. Subsequent research was by Patricia Sánchez Abril, Avner Levin, and Alissa Del Riego entitled " Blurred Boundaries: Social Media Privacy and the Twenty-FirstCentury Employee". His research concludes that in the light of the ubiquity of social media, employers and employees need guidance on how to view social media in the workplace. Context and how to shape policies on their use. His research is devoted to social media and workplace. [3] Subsequent research is The distinction between privacy and data protection in the jurisprudence of the CJEU and the EctHR conducted by Juliane Kokott and Christoph Sobotta . This research is also linked to the jurisprudence of the CJEU and the EctHR. [4] Other related researches are Privacy and 
Law Enforcement in the European Union: The Data Retention Directive conducted by Francesca Bignami [5]. This research is also devoted to the protection of privacy in the European Union. From the various studies mentioned above, it is only devoted to the study of privacy data protection in certain regions, and so far there has been no study of legal protection studies on the privacy data of social media users studied in relation to the legal system in Indonesia. Therefore it is necessary to conduct research studies related to legal protection for privacy data of social media users which are also linked to international and national law. This also cannot be separated from the fact that the Indonesian community is one of the largest social media users in the world.

Previous author's research is related to legal protection of customers' personal data in administering internet banking services. Starting from the importance of legal protection on privacy data, especially now associated with the development of social media, the purpose of this study is to find the concept of how international law and the national legal system regulate the protection of privacy data of social media users and the extent of their implementation. - What obstacles arise in the effort to protect the privacy of social media users.

\section{METHOD}

In this study, researchers used the following methods:

\section{Approach Method}

The approach method used is a normative juridical approach, which is a study that emphasizes research on library material or secondary data, which includes: [6]

a. Primary legal materials, namely legislation, international conventions, international customary law, principles of international law, decisions of the International Court of Justice, and doctrines that apply in the law of air.

b. Secondary legal materials, namely materials that can help analyze and understand primary legal materials, such as research results, scientific works in the form of books, journals, papers and other literature whose substance is relevant to this research.

c. Tertiary legal material, which is material that provides information about primary and secondary legal materials, such as legal dictionaries (Black's Law Dictionary).

This research examines and examines secondary data relating to privacy data protection, and at this stage grammatical interpretation is carried out, namely interpreting the words of the relevant legislation, systematic interpretation of the law by linking one law with the law other laws, authentic legal interpretation that can be done by looking at the explanations of the legislators themselves.

\section{Research Specifications}

The research carried out is analytical descriptive, which describes national and international legal instruments associated with legal theories and their practice related to the object of research. [7] The description concerns the facts systematically in the form of secondary data on primary legal material, namely the law, secondary data of secondary legal material, namely the opinions of experts (doctrine) relating to the implementation of privacy protection of social media users, as well as secondary data on legal material. Tertiary like legal dictionary.

3. Data collection technique

In this study data collection techniques were carried out in two stages, namely:

a. Library research (library research), in this case the researchers conducted a study of secondary data primary legal materials in the form of legislation, as well as other related regulations. In addition, it also examines secondary data of secondary legal material in the form of scientific works of experts in the field of law and is supported by research on secondary data on tertiary legal materials.

b. The field research (field research), in this case only as supporting data in research to support and complement the study of literature, by conducting a structured interview (guided interviews) with relevant parties.

4. Data Analysis

All data obtained analyzed on a juridical qualitative. In thing this analysis do with pay attention hierarchy regulation legislation for regulation legislation of the no contradictory with regulation other legislation and achieved it certainty law.

\section{Location Research}

The location of the study was carried out in several places, including: Padjadjaran University Postgraduate Library, Faculty of Law Library, Padjadjaran University, Indonesian Computer Library, and several websites in the internet system.

\section{RESULT}

A. Aspects of International and National Law in Social Media User Privacy Data Protection. The universal Declaration of Human Rights is the first international instrument that protects a person's privacy rights. Privacy arrangements in the first international instrument are included in Article 12 of the UDHR, namely:

"No one shall be subjected to arbitrary interference with his privacy, family, home or correspondence, nor attacks upon his honors and reputation. Everyone has the right to protect against attacks. "

Substantially, the privacy regulation in Article 12 of the UDHR provides very broad protection because it includes the right to: [8]

1. Physical privacy

Physical privacy is the protection of privacy related to his place of residence.

2. Decisional privacy

Decisional privacy is the protection of privacy against the right to determine his own life including the life of his family.

3. Dignity

Dignity is protecting one's self-esteem including one's reputation and reputation.

4. Informational privacy

Informational privacy is the privacy of information which means the right to determine how a person performs and saves his privacy data. 
International Covenant on Civil and Political Rights (ICCPR) 1966

Regulations regarding privacy within the ICCPR are set out in Article 17, which contains:

1) No one shall be subjected to arbitrary or unlawful interference with his privacy, family, home or correspondence, to unlawful attacts upon his honor and reputation.

2) Everyone has the right to the protection of the law against such interference or attacts.

The scope of privacy settings in the ICCPR, namely: [9]

1. Protection of privacy for family and home (family and home).

2. Protection of privacy against the way someone corresponds.

3. Privacy protection against citizen searches or searches carried out by the Government.

4. Protection of honor and reputation.

5. Protection of privacy data (personal information).

In addition to international instruments, privacy data protection is also regulated in special instruments to protect privacy data, namely:

1. OECD Guidelines Governing the Protection of Privacy and Transborder Flows of Personal Data, 1980

2. Council of Europe Convention for the Protection of Individuals with regard to the Processing of Personal Data, 1981

3. EU Data Protection Directive, 1995

4. United Nations General Assembly Resolution concerning the Right to Privacy in the Digital Age, 2014

5. Resolution of Madrid in the International Conference of Data Protection and Privacy Commissioners

While national instruments in protecting data privacy in Indonesia are listed in various provisions including:

1945 Constitution

Constitutionally, the guidelines for regulating privacy data protection are based on the mandate in the opening of the 1945 Constitution in which this is implied as stated in the second and fourth paragraphs of the Preamble to the 1945 Constitution.

Opening of the second paragraph of the 1945 Constitution which states that:

"And the struggle for the Indonesian independence movement has come to a happy time, safely sentosa, to lead the Indonesian people to the front gate of the independence of the Indonesian state, which is independent, united, sovereign, just and prosperous".

The implicit meaning of the word fair and prosperous in the second paragraph is justice that is intended for all Indonesian people. In addition, the implementation of state objectives is mandated in the fourth paragraph of the Preamble to the 1945 Constitution which states that:

"Then than that to form a Government of the Republic of Indonesia that protects all the people of Indonesia and all of Indonesia's bloodshed and to advance the general welfare, ...".

Protection of privacy data other than based on the second and fourth paragraphs of the Preamble, there is also a strong foundation contained in the body of the 1945 Constitution, namely first in Article 1 Paragraph (3) of the 1945 Constitution which states that the state of Indonesia is a legal state. The formulation of the article becomes the basic foundation that in the event that any activity including activities in social media must be given legal certainty in order to fulfill the element as a state of law. Then the formulation of the next article is in Article $28 \mathrm{G}$ of the 1945 Constitution which states that:

"Every person has the right to protection of his personal, family, honor, dignity, and property under his control, as well as the right to a sense of security and protection from the threat of fear of doing or not doing something which is a human right".

Based on these provisions, the 1945 Constitution does not explicitly mention privacy and protection of privacy data, in this case included in the scope of protection of human rights.

Law Number 39 of 1999 concerning Human Rights In Article 29 paragraph (1) the 1999 Human Rights Law recognizes the right of everyone to the protection of their personal, family, honor, dignity and property. As well as information regarding Article 14 Paragraph (2) and Article 32 related to protection of information and personal privacy data.

Constitution of electronic information and transaction

In Law 19 of 2016 concerning Amendments to Act 11 of 2008 concerning ITE regulated on the protection of privacy data and privacy rights in Article 26 paragraph 1, therefore the use of any privacy information and data through electronic media carried out without the consent of the owner of the data is a violation of rights privacy.

Law Number 36 of 1999 concerning Telecommunications

In the Law on Telecommunications, among others is regulated in Article 22 related to the prohibition of unauthorized access, then Article 40 in the case of wiretapping of information, as well as speaking the confidentiality of the privacy data of telecommunication service users regulated in Article 42 paragraph (1), the last said criminal sanction is in Articles 56 and 57. 
B. Implementation of International and National Provisions in Protecting Social Media User Privacy Data

International provisions related to the protection of data on the privacy of social media users so far have not been implemented optimally, given the international provisions that exist, the Universal Declaration of Human Rights is still limited to normative juridical provisions in the international arena that cannot be optimally enforced. ICCPR in this case has not been able to reach optimal legal protection in the protection of privacy data, this can be seen from the existence of cases of violations of the privacy of social media users that cannot be prevented or handled optimally.

The existence of national provisions in Indonesia regarding privacy data protection is still spread in various national provisions. This also resulted in the implementation of legal protection for privacy data of social media users has not run optimally. The current weaknesses of Indonesia do not have specific privacy data protection laws.

\section{Constraints in Social Media User Privacy Data Protection Efforts}

Constraints in terms of legal protection for the privacy data of social media users, namely first, normatively juridical, Indonesia does not yet have special arrangements in the field of privacy data protection and its legal mechanism. Non-legal constraints include lack of understanding for the public of the importance of maintaining privacy data and understanding of the vulnerability of misuse of privacy data on social media.

\section{DISCUSSION}

The rapid development in information technology and the globalization of all systems has made things easier. Various fields of life have been dominated by sophisticated technology systems, one of which is through internet media. Supported by the development of computer technology and the increasingly advanced online communication makes the information ready to be communicated to those who are authorized to know the information and those who might abuse it. The protection of data is the fundamental rights human rights. ${ }^{1}$

In general there are three aspects of privacy, namely: [10]

1. Privacy regarding someone's personal ( Privacy of a

Person's Persona )

The right to privacy is based on the general principle that everyone has the right to be left alone (the right to be let alone).

2. Privacy of data about someone ( Privacy of Data About a Person )

${ }^{1}$ Sinta Dewi Rosadi, Konsep Perlindungan Hukum Atas Privasi dan Data Pribadi Dikaitkan dengan Penggunaan Cloud Computing, Jurnal Yustisia, Edisi 94, Januari - April 2016, page 5 .
Privacy rights can also bind to information about someone collected and used by others. In short, this privacy is called personal data.

3. Privacy of one's communication (Privacy of Person's Communications )

In certain situations, the right to privacy can also include on-line communication.

Legal protection for privacy data in the use of social media can be done in the form of preventive legal protection, namely the approach to self-regulation and government regulation and international regulation. The use of selfregulation can be applied by companies that launch social media services by implementing privacy policies, notification and also consumer education. In addition, in the principles of fair information practice, all companies that create, maintain, use or distribute records of identifiable personal information should take responsibility for ensuring their trust in these objectives and can be responsible for preventing and protecting personal information that is lost, damaged, and misused. The company should also guarantee that the level of protection is extended to third parties whose personal information is transferred that can be compared with their ownership.

Government regulation can be realized through steps to form law in the field of privacy data protection, not only in the use of social media but in various fields involving data transmission in internet or digital telecommunications. In the national legal system, Indonesia itself has a weakness, namely the absence of laws protecting personal data. This is certainly a challenge for the government in providing legal certainty for the community, especially in terms of protecting the privacy of social media users.

International regulation in this case namely the aspect of international law in the field of protection of personal data so far has been seen in various international conventions related to the protection of personal data which also begins with the recognition of human rights. This is because the protection of personal data enters the scope of the regulation of human rights.

\section{V.CONCLUSION}

Based on the results of the study, it can be seen that in the international provisions privacy data protection has been spread in various international conventions including the Universal Declaration of Human Rights and the International Covenant on Civil and Political Rights, while the provisions relating to the protection of privacy data in Indonesia currently have no laws specifically regulate the protection of personal data, even though there are several laws and regulations relating to personal data including the Law on Human Rights, Information and Electronic Transactions Laws, and the Law on Telecommunications. So far, various national provisions have not been able to provide legal protection optimally, one of which is due to the lack of specific provisions related to the protection of privacy data. Constraints that arise in the effort to protect the privacy of 
social media users, consist of legal and non-legal constraints. Legal constraints include the lack of provisions or more specific policies in the regulation of privacy data protection and legal mechanisms. Non-legal constraints are in terms of education to users, where there are still many social media users who do not realize the importance of protecting personal data.

\section{REFERENCES}

[1] Elena Izyumenko, Think Before You Share: Personal Data on Sites in Europe: Article 8 ECHR as a tool of Privacy Protection , Master Thesis Faculty of Law Lund University, 2011, p. 76.

[2] Brendan van Alsenoy, Regulating Data Protection, The Allocation of Responsibility and Risk among Actors Involved in Personal Data Processing, Doctor of Law Research, Faculty of Law, Leuven Center for IT and IP Law, 2016, p. 5.

[3] Patricia Sánchez Abril, Avner Levin, and Alissa Del Riego, Blurred Boundaries: Social Media Privacy and the Twenty-First-Century Employees, American Business Law Journal, Volume 49, Issue 1, 63124, Spring 2012
[4] Juliane Kokott and Christoph Sobotta, The Difference between privacy and data protection in the jurisprudence of the CJEU and the EctHR, International Data Privacy Law, 2013, Vol. 3, No. 4

[5] Francesca Bignami , Privacy and Law Enforcement in the European Unio : The Data Retention Directive, Chicago Journal of International Law, Volume 8, Number 1, Article 13, 2007.

[6] Sinta Dewi Rosadi, Konsep Perlindungan Hukum Atas Privasi dan Data Pribadi Dikaitkan dengan Penggunaan Cloud Computing, Jurnal Yustisia, Edisi 94, Januari - April 2016.

[7] Ronny Hanitijo Soemitro, Metodologi Penelitian Hukum dan Jurimetri , Ghalia Indonesia, Semarang, 1988.

[8] Sinta Dewi Rosadi, Cyber Law: Aspek Data Privasi Menurut Hukum Internasional, Regional, dan Nasional, Refika Aditama, Bandung, 2015.

[9] Soerjono Soekanto and Sri Mamudji, Penelitian Hukum Normatif Suatu Tinjauan Singkat, Raja Grafindo Persada, Jakarta, 1995.

[10] Edmon Makarim, Kompilasi Hukum Telematika, Cet. II, Jakarta: PT. Raja Grafindo Persada, 2004. 